\title{
HIGH RESOLUTION DIGITAL 3D MODELLING OF SUBSURFACE MORPHOLOGICAL STRUCTURES OF KOUTOUKI CAVE, GREECE
}

\author{
VISOKOLOČLJIVOSTNO DIGITALNO 3D MODELIRANJE \\ PODZEMELJSKIH MORFOLOŠKIH STRUKTUR V JAMI \\ KOUTOUKI, GRČIJA
}

\author{
Aliki KONSOLAKI ${ }^{1}$, Emmanuel VASSILAKIS ${ }^{1, *}$, Leonidas GOULIOTIS ${ }^{1}$, Georgios \\ KONTOSTAVLOS ${ }^{2} \&$ Vassilis GIANNOPOULOS ${ }^{3}$
}

\begin{abstract}
UDC 528.8.044.6:551.44(495)

Aliki Konsolaki, Emmanuel Vassilakis, Leonidas Gouliotis, Georgios Kontostavlos \& Vassilis Giannopoulos; High resolution digital 3D modelling of subsurface morphological structures of Koutouki Cave, Greece

Remote sensing techniques and laser scanning technology have given us the opportunity to study indoor environments, such as caves, with their complex and unique morphology. In the presented case study, we used a handheld laser scanner for acquiring points with projected coordinate information (X, Y, Z) covering the entire show cave of Koutouki; including its hidden passages and dark corners. The point cloud covers the floor, the walls, and the roof of the cave, as well as the stalactites, stalagmites and the connected columns that constitute the decoration of the cave. The absolute and exact placement of the point cloud within a geographic reference frame gives us the opportunity for three-dimensional measurements and detailed visualization of the subsurface structures. Using open - source software, we managed to make a quantification analysis of the terrain and generated morphological and geometric features of the speleothems. We identified 55 columns by using digital terrain analysis and processed them statistically in order to correlate them to the frame of the cave development. The parameters that derived are the contours, each column height, the speleothem geometry and volume, as well as the volume of the open space cavity. We argue that by the demonstrated methodology, it is possible to identify with high accuracy and detail: the geomorphological features of a cave, an estimate of the speleogenesis, and the ability to monitor the evolution of a karstic system.

Key words: cave, laser scanner, 3D representation, speleothems, SLAM.
\end{abstract}

Izvleček UDK 528.8.044.6:551.44(495) Aliki Konsolaki, Emmanuel Vassilakis, Leonidas Gouliotis, Georgios Kontostavlos \& Vassilis Giannopoulos; Visokoločljivostno digitalno 3D modeliranje podzemeljskih morfoloških struktur $v$ jami Koutouki, Grčija

Daljinsko zaznavne tehnologije in laserji nam omogočajo raziskovanje zaprtih prostorov, kot so jame z njihovo kompleksno in edinstveno morfologijo. Za pridobivanje različno dostopnih podatkov v turistični jami Koutouki smo v študiji uporabljali ročni laserski skener. Točkovni oblak pokriva tla, stene in strop jame ter stalaktite, stalagmite in stebre, ki prispevajo k okrasju jame. Natančna postavitev točkovnega oblaka v referenčnih geografskih okvirjih daje možnost tridimenzionalnih meritev in podrobne vizualizacije struktur v podzemlju. S podrobno analizo terena smo opredelili 55 stebrov in jih uvrstili v okvir razvoja jame. Pridobljeni so bili podatki o strukturiranosti, višini vsakega stebra, obliki in prostornini tamkajšnjih siginih tvorb ter prostornini prostega jamskega prostora. Z uporabljeno metodologijo je torej mogoče podrobno in $\mathrm{z}$ veliko natančnostjo opredeliti geomorfološke značilnosti jame, predvideti potek speleogeneze in spremljati razvoj kraškega sistema.

Ključne besede: jama, laserski skener, 3D prikaz, sigine tvorbe, SLAM.

\footnotetext{
${ }^{1}$ Remote Sensing Laboratory, Faculty of Geology \& Geo-environment, National and Kapodistrian University of Athens, Panepistimiopolis, 15784 Zographou, Greece, e-mails: alikikons@geol.uoa.gr, evasilak@geol.uoa.gr, lgouliotis@gmail.com

${ }^{2}$ Hellenic Speleological Society, Sina 32, 10672 Athens, Greece, e-mail: george.kontostavlos@gmail.com

${ }^{3}$ Ministry of Culture, Ephorate of Palaeoanthropology and Speleology, Ardittou 34b, 11636 Athens, Greece, e-mail:

billgiannopoulos@yahoo.gr

* Corresponding Author
}

Received/Prejeto: 26.11.2019

DOI: $10.3986 /$ ac.v49i2-3.7708 


\section{INTRODUCTION}

The present work addresses 3D mobile mapping innovative technology complementary to our methodology in acquiring and processing an integrated 3D model of a cave system. Usually, cave systems are complex and unique because of their distinctive geometry and compound geomorphology along with natural harsh conditions such as constrained accessibility, limited light, high humidity and possible existence of water. Such environments make mapping difficult and further complicated (Kershaw 2012). Conventional methods of cave mapping usually include the manual measurement of the area and the bearing between an array of stations commonly spaced up to a few tens of meters apart (Warild 2007; Ballesteros et al. 2014). The traditional measurement tools include a laser range finder, a mining compass, and an inclinometer, which are commonly used by surveying teams, combined with free-hand drawings in some or all of the stations for more detailed results. In each station, distance measurements up to the roof and floor, as well as left and right walls are required. With the evolution of technology, distance measurements can be estimated by laser distance measurers which decreases the manual errors and can be viewed on a mobile device. Although these methods have been considered as highly detailed even in very narrow passages, long time work and physical effort are required, often under high-risk conditions (Buchroithner 2015).

Nowadays, the state-of-the-art in surveying open surface is based on LiDAR technology. Lately, similar technology has started to be used for indoor surveying and consequently in cave mapping, especially where the underground space allows. The most efficient way for tracing cave systems is by using Terrestrial Laser Scanning (TLS) equipment (Buchroithner \& Gaisecker 2009). A single terrestrial laser scan contains millions of $\mathrm{x}, \mathrm{y}, \mathrm{z}$ measurements resulting in a three-dimensional (3D) point cloud within minutes (Gallay et al. 2015). Although terrestrial scanners produce faster and highly detailed results, their use in demanding environments like caves can be restricted. The necessity of a multitude of stations throughout the cave to avoid scanning shadows due to occlusions in the point cloud, make the operation difficult for the surveyor due to the considerable weight of the equipment and the adjustment of the scanner in a stable tripod (Holenstein 2011). Lindgren and Galeazzi (2013) argue that over 350 scans are needed to be made in 9 chambers of a cave's network in Las Cuevas, Belize for the different scans to overlap each other efficiently.

Therefore, our research was based on the use of a recently released piece of equipment introducing a lightweight mobile handheld laser scanning system (GeoSLAM ZEB - REVO) that can produce a quite dense point cloud within an underground cavity. Using narrow infrared laser pulses, the laser sensor measures thousands of points $(\mathrm{x}, \mathrm{y}, \mathrm{z})$ within seconds. The $\mathrm{x}, \mathrm{y}, \mathrm{z}$ point cloud is generated while the operator simply walks through the cave holding the scanning device (Zlot \& Bosse 2014). Consequently, for complex volumetric landscape features such as caves with narrow corridors, vertical walls

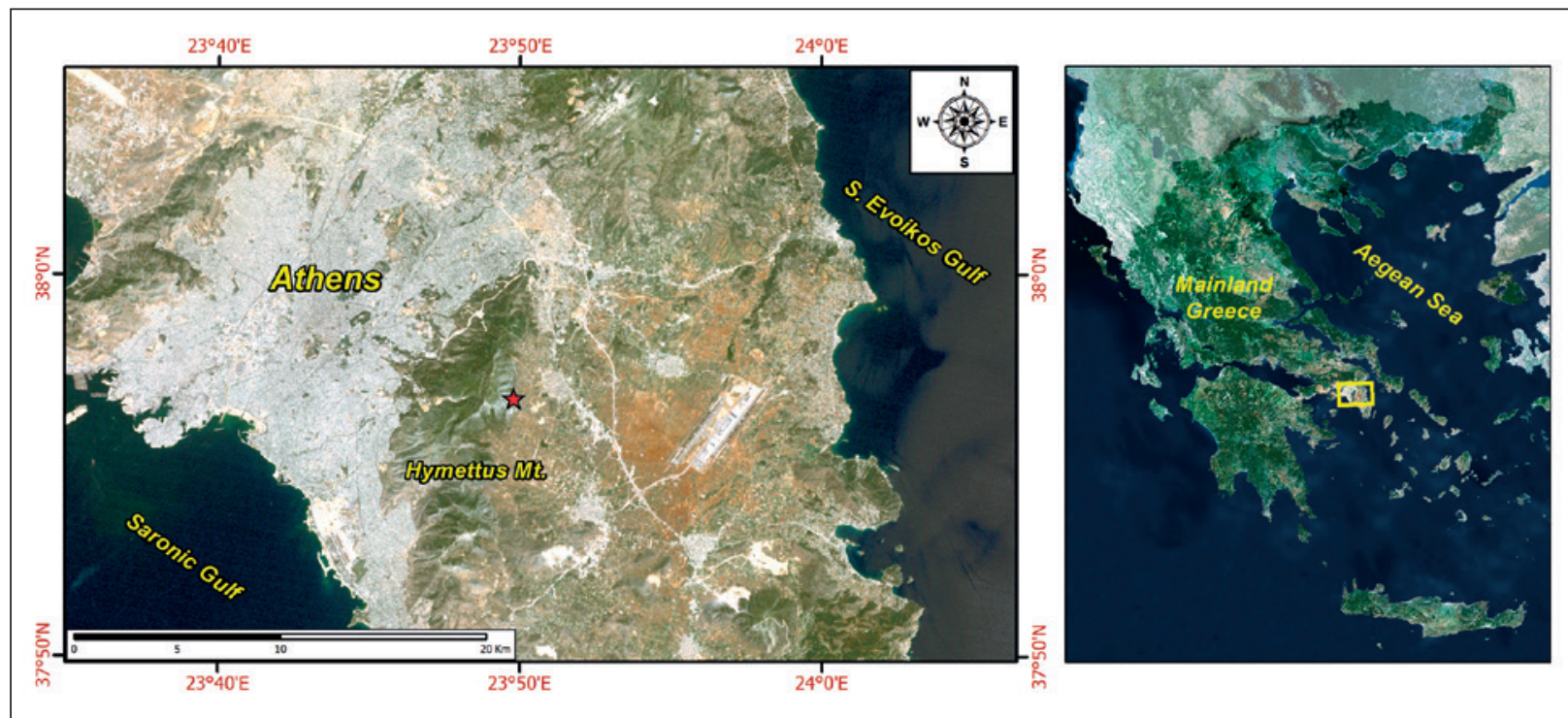

Fig. 1: The Koutouki cave location (red star) on a Landsat-7ETM+ image of Attica (321/RGB). The map on the right shows the location of the Landsat image in mainland Greece. 
and the absence of light, mobile laser scanner seems to be the ideal solution. The lack of light incapacitates the use of camera and consequently, RGB color values and intensity cannot be recorded. By acquiring the point cloud, a three - dimensional model is generated which after post- processing may be used for detailed mapping in real, high accurate coordinates and several volumetric measurements.

\section{STUDY AREA}

The testing was held at "Koutouki" cave which is situated on the north-eastern side of Hymettus mountain at the suburban area of Athens and it stretches at an altitude of $510 \mathrm{~m}$, within the Jurassic thick-bedded marbles of Attica Geotectonic Unit (Lekkas \& Lozios 2000). It is the biggest and most popular show cave of Attica operated by the Ministry of Culture for the last 40 years (Fig. 1). There are two entrances of the cave, the natural entrance (a shaft of 38 meters) which lies in the northwest side of the cave, and the artificial entrance which was opened for the commercial use of the cave and lies in the northeast side of the cave. The total length of the main corridor is about $350 \mathrm{~m}$, the inner annual temperature of the cave fluctuates between $14-17^{\circ} \mathrm{C}$ and the average air humid- ity is $87 \%$. According to Dermitzakis and Lekkas (1977), the formation of karst and the age of the creation of the cave is pre - Pliocene, and the cave consists of two main corridor types. Narrow and high corridors were created by following the joint sets trend, and significant calcite quantities are found filling the vacuum created by the almost vertical discontinuities (joints, faults, and bedding). This type of opening is found both in the natural and artificial entrances of the cave. Low height and wide corridors were created because of the subsurface erosion which made enough open space for large blocks to fall off the roof and side walls due to collapsing, following the bedding of the marble that is forming the ceiling parallel to it (Mariolakos \& Lekkas 1974).

\section{METHODOLOGY AND DATA ACQUISITION}

The entire "Koutouki" Cave was surveyed with a Geo Slam Zeb - Revo mobile mapping device. The specifications of this equipment include a $360^{\circ}$ rotation, a (class 1 eye-safe) $100 \mathrm{~Hz}$ laser - making 100 rotations per second with a collection of 43,200 points per second. The maximum effective range is around $25-30 \mathrm{~m}$ for indoor environment and any point data captured over $30 \mathrm{~m}$ is usually excluded by default. In order to concurrently map and navigate through an unknown environment where no external positioning system is available, the trajectory can be estimated based entirely on the LiDAR and its inertial measurements, creating an algorithm that can utilize information from sensors to compute a best estimate of the device's location and a map of the environment around it. With Simultaneous Localization and Mapping algorithm (SLAM) (Durrant-Whyte \& Bailey 2006 and references within) the loop closures do not occur at discrete stations, but are rather detected automatically and continuously as parts of the environment are rescanned (Zlot \& Bosse 2014). The Zeb - Revo device uses the SLAM algorithm to utilizes data from a Lidar sensor and an industry-grade Inertial Measurement Unit (IMU). The IMU estimates an initial position and uses extracted Surface Elements (Surfels) to represent a dense set of points generating the point cloud (Pfister et al. 2000). Then the IMU calculates the trajectory and new Surfels are extracted. The two sets of Surfels are then used to combine the point clouds and subsequently correct and smooth the trajectory estimation. Following this iterative process, the final point cloud is regenerated based on the new smoothed best-estimated trajectory. To optimize the trajectory and limit any IMU drift, a closed loop is performed such that the start and finish environments can be accurately matched.

\section{COLLECTION OF EXISTING DATA, VISIT AND PHOTOGRAPHIC DOCUMENTATION}

Before the field-work, extensive retrieving of all available documents, chronological records, and map information for access to Koutouki Cave was made at the historical archives of the Hellenic Speleological Society. Formal permission by the Paleoanthropology and Speleology of the Greek Ministry of Culture had to be granted before any activity at the areas inside or at the surroundings of the cave. After personal communication with several members of the Speleological community, it was mentioned that the first explorer of the cave was the journalist $\mathrm{K}$. D. Chatzopoulos in November of 1928. Later, speleolo- 


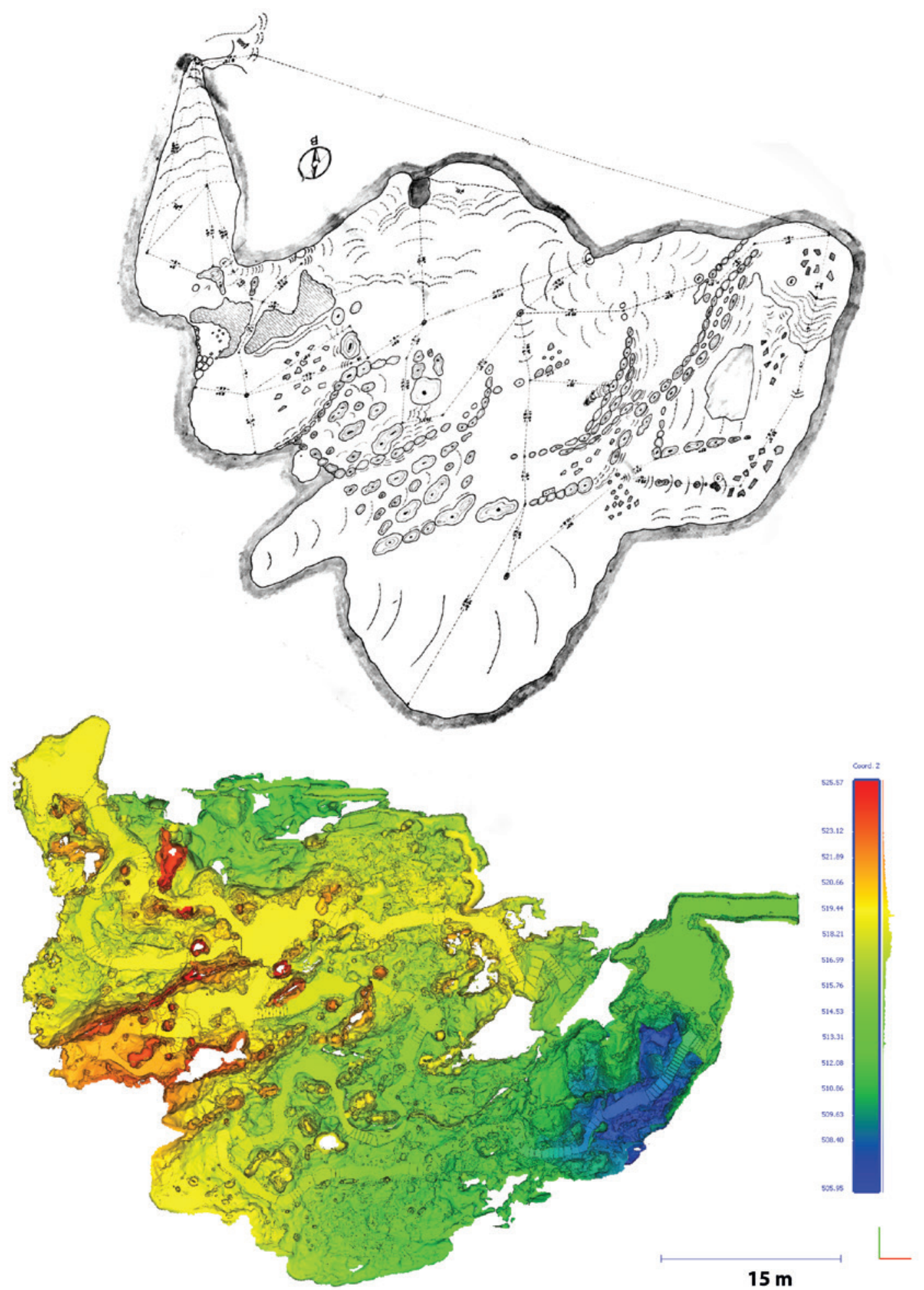

Fig. 2: Comparison between (a) Historical Map of Koutouki Cave with traditional methods in 1963 and (b) detailed high-resolution top view of the cave as represented with a 44,500,000 point cloud acquired with the handheld laser scanner. 
gists Ioannis Petrocheilos and Anna Petrocheilou studied and mapped the cave for the first time in 1955 (archive of Hellenic Speleological Society). The mapping with traditional procedures was completed by Anna Petrocheilou in 1963 (Papavlasopoulou 2009) with the addition of the construction of the artificial entrance that was created for the commercial use of the cave. Since then, there has been no other recorded mapping of Koutouki Cave until this present work (Fig. 2).

\section{LASER SCANNING PHASE}

We wore a backpack and held the Zeb - Revo device for the scanning process of Koutouki Cave which was established in less than an hour, following the main cor- ridor - touristic route with small breaks when needed. The mobile device was much more effective, especially in narrow spaces outside the main route where larger equipment requires a survey tripod with the possibility of a lack of data due to "shadowing" to be rather expected. The entire cave contains many impressive geomorphological features such as speleothems which were entirely included in the scan (Fig. 3). The artificial entrance, as well as the outdoor space in the surrounding area were also scanned, requisite for the later post-processing georeferencing procedure. The natural entrance of the cave is a $38 \mathrm{~m}$ shaft and therefore it could not be reached, as the maximum indoor range of the handheld laser scanner cannot exceed $30 \mathrm{~m}$. We have overcome this distance

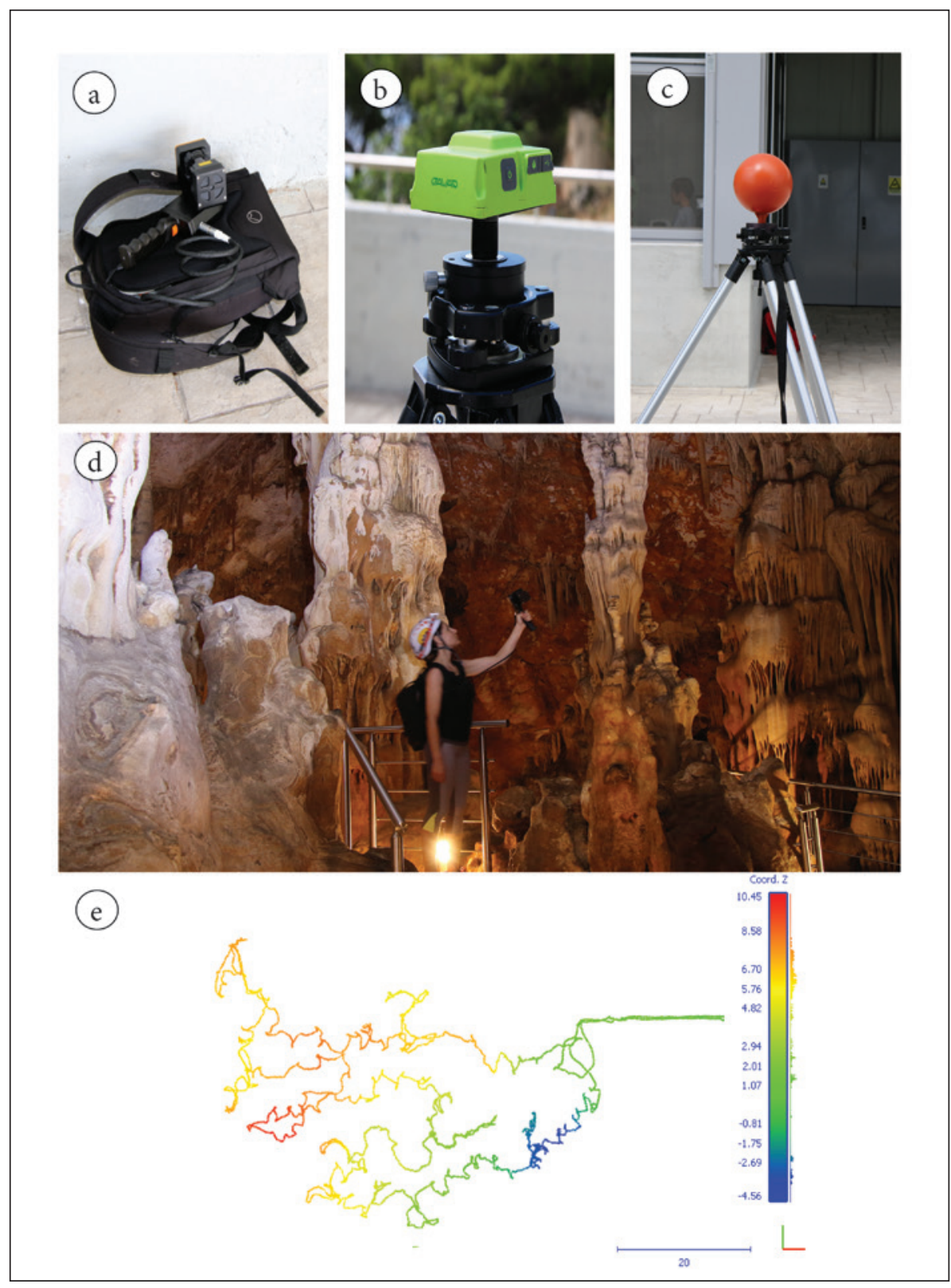

Fig. 3: Cave Survey. (a) The GeoSlamZeb - Revo laser scanning system equipment, (b) The Triumph - 2, JAVAD GNSS used for the georeferencing procedure, (c) One of the spherical targets which were used for georeferencing the point cloud, (d) The scanning device is held in the operator's hand during the data acquisition, who is also wearing a backpack with the battery inside (Photo: V. Giannopoulos), (e) The scanning walkthrough in which the color scale represents the relative elevation in meters, set as $0 \mathrm{~m}$ at the starting point at the artificial entrance (Photo: V. Giannopoulos $(a-d))$. 
problem by mounting it onto an extending pole in to improve the point cloud and to achieve much better results. To start acquiring the point data, the procedure involves powering up the equipment, waiting for the initialization procedure, and then, start scanning. After accomplishing the data collection, the device was put down, so that the re-initialization could begin, and the data measurements were compressed and transferred to a USB flash drive. The final point cloud contained more than 80 million points representing the entire show cave, including the shaded areas and chambers, which are not visible or able to be visited by any guest just walking on the visitor's trail.

\section{ESTABLISHING GNSS BASES AND GEO- REFERENCING}

The next phase involved geo-referencing the point cloud, to transform the registered point cloud from its local coordinate system to the Hellenic Geodetic Reference System (HGRS' 87) (Mugnier 2002). The reliability of the methodology is ensured by measuring the geodetic coordinates of at least three non- collinear signalized markers outside the cavity system using Global Navigation Satellite Systems (Gallay et al. 2015). We established two bases of spherical targets $(r=0.075)$ at the open air surrounding cave area, which we used as reference targets; the center of each was defined as a registration point (Fig. 3b-c). The spheres were scanned along with the surrounding environment, including the entrance of the cave, which was also part of the cavity point cloud, in order to have sufficient overlapping and eliminate errors. A third marker was also measured at the natural entrance of the cave about $300 \mathrm{~m}$ away and $50 \mathrm{~m}$ higher in elevation. The registration points were measured with the use of a Triumph - 2, JAVAD GPS. The overall accuracy of the georeferenced point cloud was estimated to be less than $1 \mathrm{~cm}$, as this is apparent from the RTK - GNSS positioning error solution.

The synchronization of the GNSS registration points with the point cloud for the geo-referencing process was made possible in Cloud Compare v.2.10.2. software which is an open-source (Girardeau-Montaut 2011), point cloud processing software developed for civil engineering and manufacturing quality control purposes.

\section{INTERPRETATION - PROCESSING AND \\ VISUALIZATION OF THE POINT CLOUD}

After registration and point cloud geo- referencing, the methodology includes the interpretation processing of the data. The initial step in the processing is to generate a triangular $3 \mathrm{D}-$ mesh. There is plenty of commercial or open-source software that can be used for creating a 3D
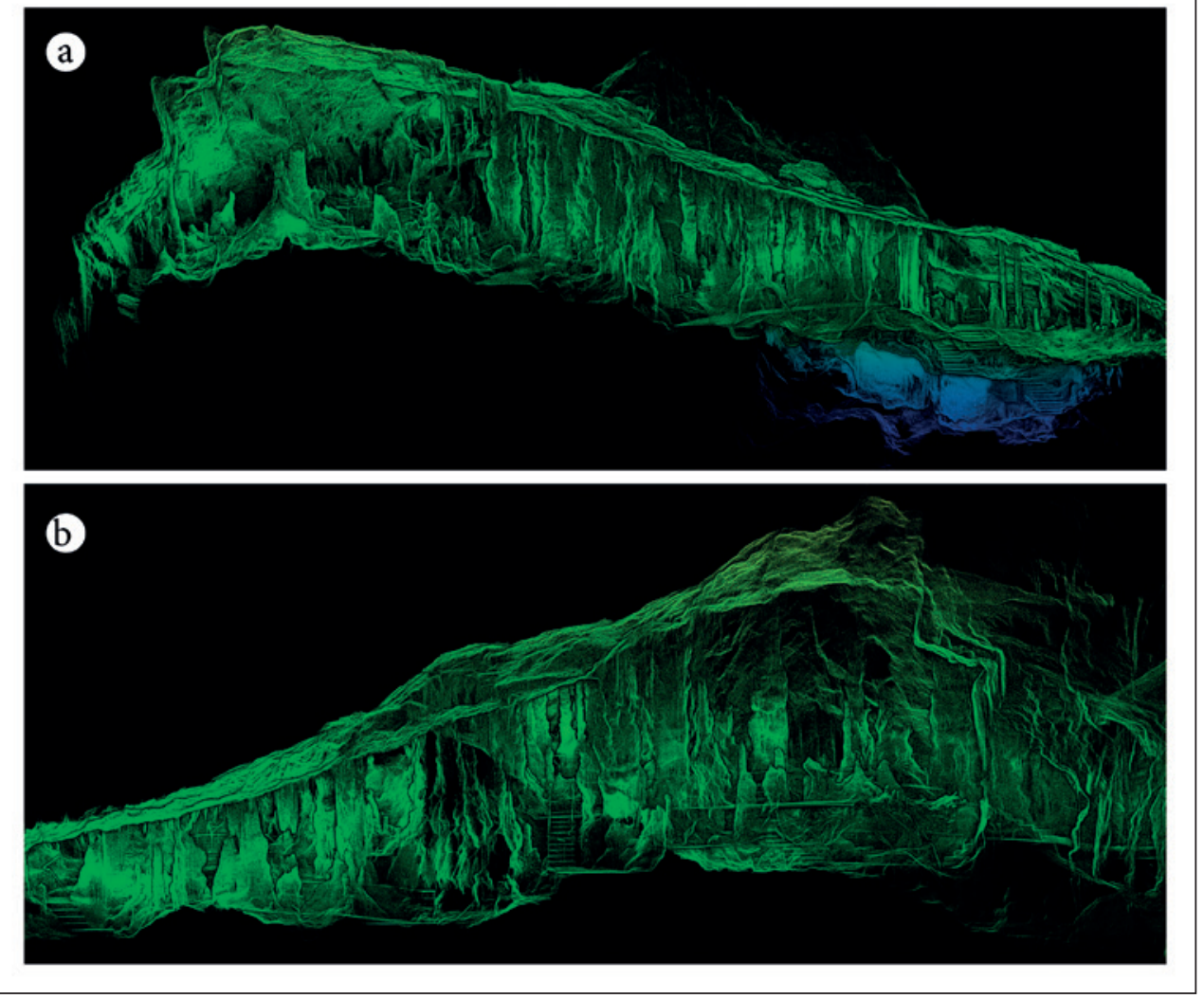

Fig. 4: Different aspects of the point cloud looking north (a) and south (b). The color scale represents the elevation variation, whilst parts of the scanning have been removed to reveal the speleothems and delete human artifacts (stairs, passage, platform). 


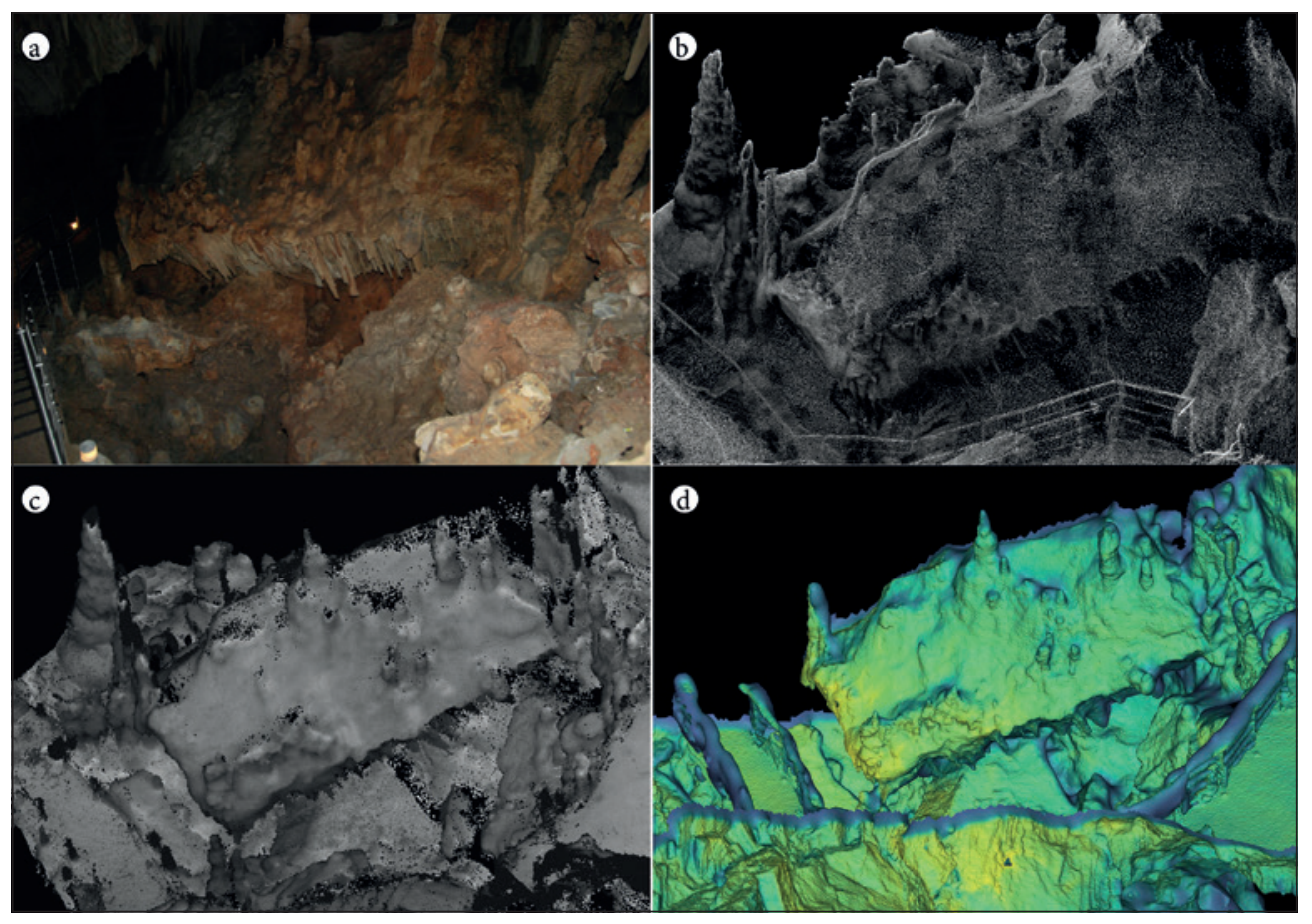

Fig. 5: A marble block (7 meters long, 3 meters high) fell off the ceiling resulting in two generations of speleothems deflected from each other. (a) Photograph of the block, (b) Point Cloud representing the same block, (c) Image of the 'Normals', (d) Resulted from mesh using Poisson Surface Reconstruction tool with an octree depth (set at 12) and 1 sample per node.

(a)

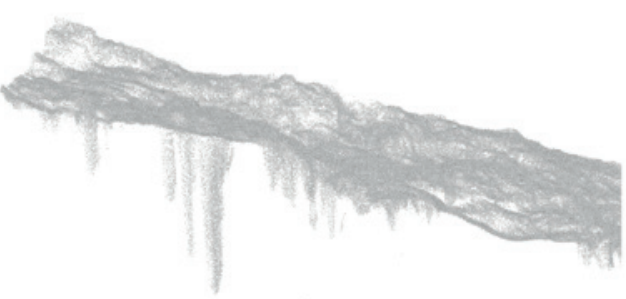

c)

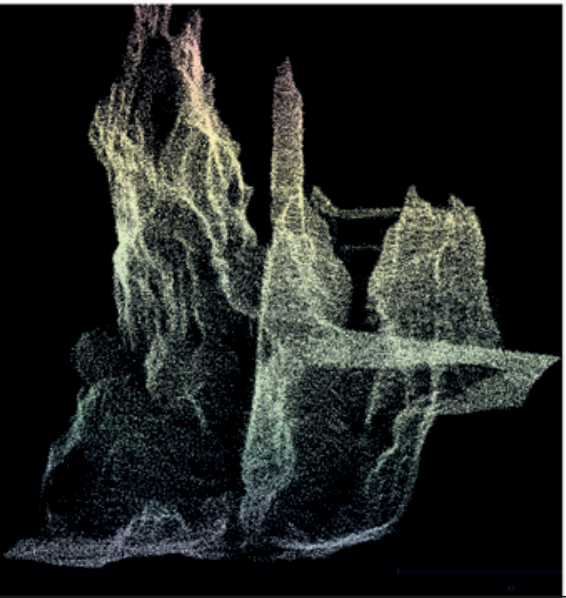

(b)
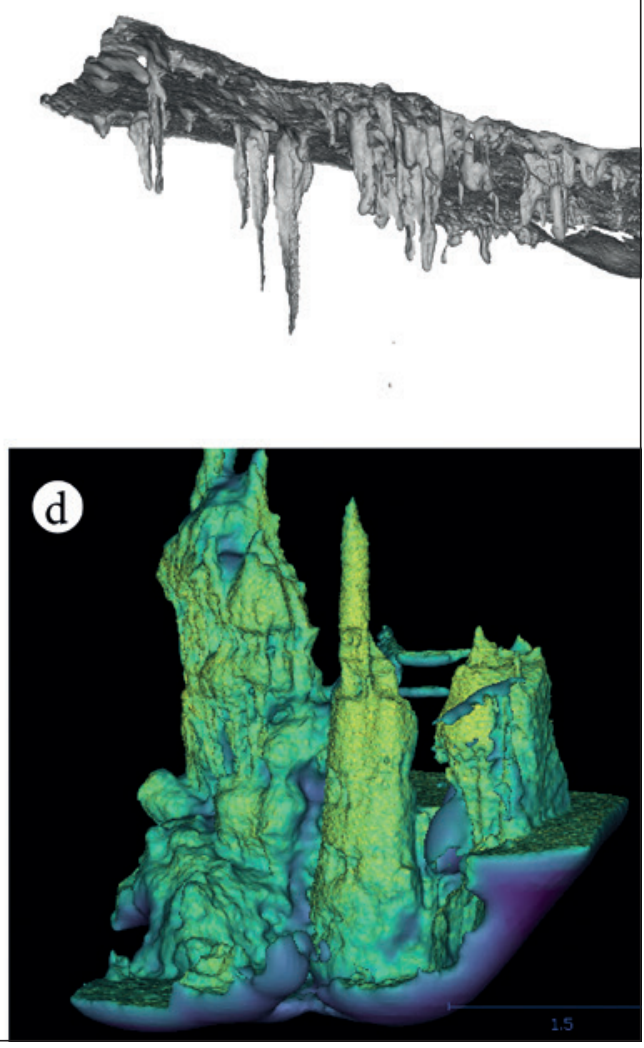

Fig. 6: Samples of surface models in smaller parts of the cave. Roof (a) and floor (c) subsets from the initial point cloud, while (b) and (d) represent the same parts after finishing meshes were generated. 
Surface Model such as Cloud Cube by AutoCAD (Canevese et al. 2013) and MeshLab by ISTI (Silvestre et. al. 2015), however, we preferred the use of Cloud Compare v.2.10.2 for modeling the Koutouki Cave (Fig. 4).

The preprocessing procedure consisted of filter- ing the point cloud to erase the unwanted noise such as points generated by the human presence, the artificial entrance of the cave, the tourist pathway containing the stairs, the handrails and the concrete path, along with noise generated by the equipment itself.

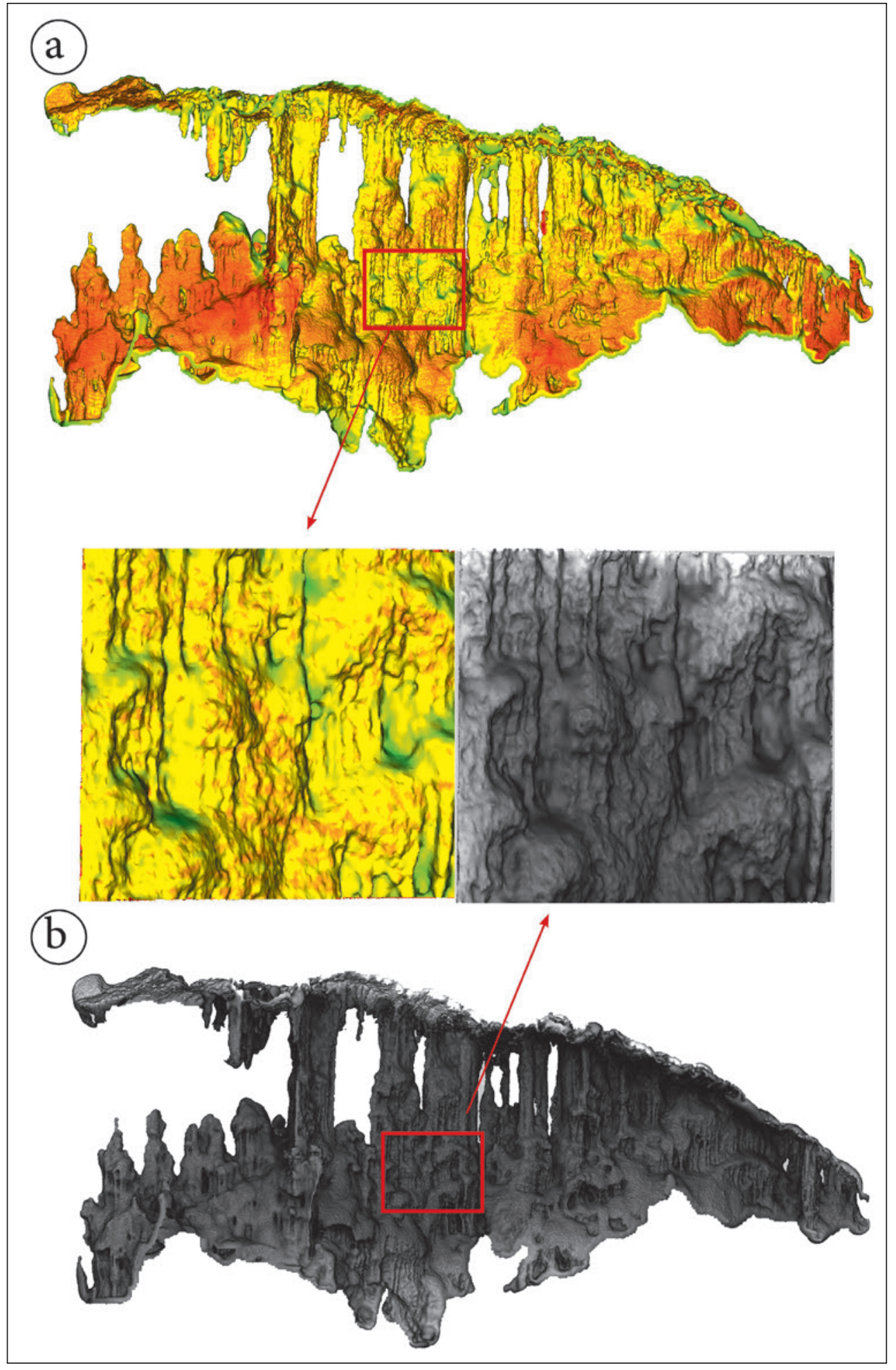

Fig. 7: Additional interpretation of the mesh by using (a) Poisson Surface Reconstruction and (b) Ambient Occlusion (PCV) filter. 
Following this process, it was important to calculate the normal vector for each point, since the originally acquired points are not assigned with a normal vector by default (Gallay et al. 2016). After computing the 'normals', there are several algorithms used to reconstruct the surface model and, in our case, Poisson Surface Reconstruction (PSR) algorithm was applied, as it is ideal for extremely irregular facets like the ones we observe in a karst system (Kazhdan et al. 2006) (Fig. 5).

The PSR algorithm creates watertight surfaces from oriented point sets and has a variable level of detail depending on the input parameters. The quality of the result depends mainly on the Octree depth parameter, in which an increase at the depth value enhances the detail at the surface. Additional parameters that PSR uses are (I) the samples per node, (II) full depth, (III) point weight, and (IV) boundary. The value we used for Octree depth was set at 13 , which was chosen after several tests and due to the processing capabilities of the running equipment. The value of samples per node was set at 1, using the Dirichlet boundary setting (Kazhdan \& Hoppe 2013).
All the other parameters were set to default. The quality of the entire cave mesh was not sufficient enough since we ascertained that some of the details were integrated, so in the next step, we built meshes in smaller sections to increase the resolution and the detail of the cave morphologies (Fig. 6).

Other filters included in CloudCompare (GirardeauMontaut 2011), like 'Portion de Ciel Visible' (PCV), 'Eye Dome Lighting' (EDL) among others, were also applied to achieve a better quality of the final 3D model. The PCV ambient occlusion filter is a shading method that gives more realistic results, whilst EDL disables 'normals', increases point size resulting in the reduction of the resolution and obfuscating the visual outcome. On the contrary, the PCV ambient occlusion filter computes the amount of incoming light from all directions for each point of the cloud to achieve better lighting for the enhancement of the cavity roughness (Fig. 7) (Duguet \& Girardeau-Montaut 2004).

\section{RESULTS}

In the next step, within a more morphometric approach, the point cloud was processed to produce several Digital Surface Models (DSMs) to make quantification analysis of the terrain by using the ArcGIS platform (ESRI 2011). The point cloud data was partitioned manually into the floor/ground subset, including the stalagmites as well as the columns of the cave (Fig. 8a) and the roof/ceiling subset, including the stalactites (Fig. 8b).

Since the point cloud was already cleaned from the unnecessary noise, both ground and ceiling points were used to create two separate DSMs with spatial analysis of $0.05 \mathrm{~m}$ using the natural neighbor triangulation method. The information that was derived from these models was sufficient to proceed to the generation of several parameters such as:

\section{GROUND CONTOURS}

The extraction of the Ground Contours (Fig. 8c) was quite significant and was created based on the floor DSM, which in turn was constructed within the ArcGIS software platform (Rigol-Sanchez et al. 2015). The predefined equidistant interval was chosen at $0.25 \mathrm{~m}$ aiming to generate contours for small but not insignificant structures. The lowest elevation of the cave is at $504.4 \mathrm{~m}$ located at the eastern side and the highest elevation is at $525.2 \mathrm{~m}$ located at the western side of the cave.

\section{COLUMNS SPATIAL DISTRIBUTION}

The Columns are represented as areas without any existing points in them and this was the criterion for creating a point cloud subset for each column. Particularly, we identified 55 columns, which is the largest percentage of the speleothem deposition volume in the Koutouki cave. They were then categorized into groups according to two criteria. First, according to the altitude at which their base is located and secondly, according to the column height, (information that would be unable or much more difficult to be acquired with any other equipment than the one described in this work). This information was classified in a geodatabase and since we have already determined the base contours, we also included the maximum elevation to finally compute the height of each column.

The highest percentage of columns is based at the mean elevation of the cave, as the floor mean elevation is at $516.3 \mathrm{~m}$ and the column base mean elevation is at $516.8 \mathrm{~m}$, which are rather identical (Fig. 9a). The lowest altitudes are located in the easternmost parts of the cave.

Additionally, a thorough spatial analysis taking into account the column height indicated that the higher columns are located on the west side of the cave as well as in the center, whilst the column heights are smaller in the north, south and eastern parts of the cave (Fig. 9b). According to the classification, there is no evidence of 


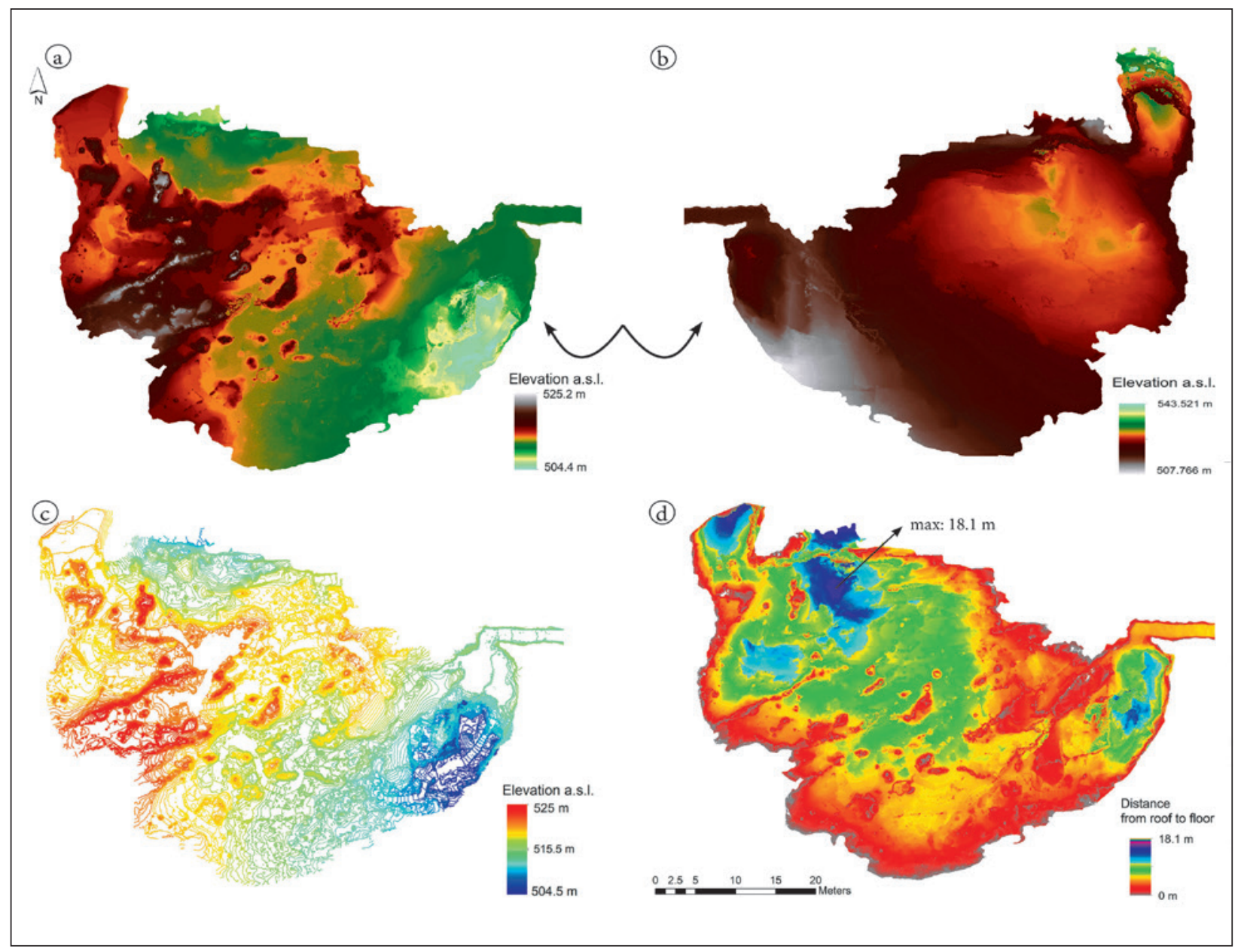

Fig. 8: (a) Digital Surface Model of the floor with a spatial resolution of 0.05 meters. The lowest elevation is at $504.4 \mathrm{~m}$ located at the southeast of the cave and the highest at $525.2 \mathrm{~m}$ located at the north - northwest of the cave, (b) Roof Digital Relief of the cave that was derived after separating the ceiling and the floor point clouds, (c) Terrain elevation contours with an interval of 0.25 m, (d) Digital Volume Model of the cavity with a spatial resolution of $0.05 \mathrm{~m}$. Cavity volume was calculated by subtracting (a) from (b) using ArcGIS raster calculator and altitude values range from 0 to $18.1 \mathrm{~m}$.

uniformity between the columns. The mean height of the columns is $2.5 \mathrm{~m}$ and their mean height of the entire cave is $3.9 \mathrm{~m}$. The highest column of the cave is located near the natural entrance and is 7.2 meters high.

The statistical analysis based on the base elevation, yields that the highest altitudes are located at the westernmost central of the cave. The largest column by width is located there and was created through the speleothem deposition phenomenon which started from the stalactite/stalagmite creation, followed by the formation of smaller columns that finally were conjoined over time, as is part of the speleogenesis procedure. In this area we found the widest column which is surrounded by a setting of other high and/or thick columns around it. From this we conclude that this area is the origin point of the cave.

\section{SPELEOTHEM AND OPEN SPACE CAVITY VOLUME}

Several speleothem volume calculations were conducted by using two different methods to cross-check the results. The primary method was based on the dimensions of the pixels representing the morphological elements of interest by limiting our data to each column. These elements have a unique grid code which was derived by the calculation of its height and that can be multiplied by the number of the pixels and its dimensions, so the volume could then be extracted. During the second method, the cave floor DSM had to be subdivided to smaller DSM parts, depending on the areas of interest we want to calculate and by using a raster calculator interface that builds and executes a map algebra expression, extracting the data statistics (including the raster's 


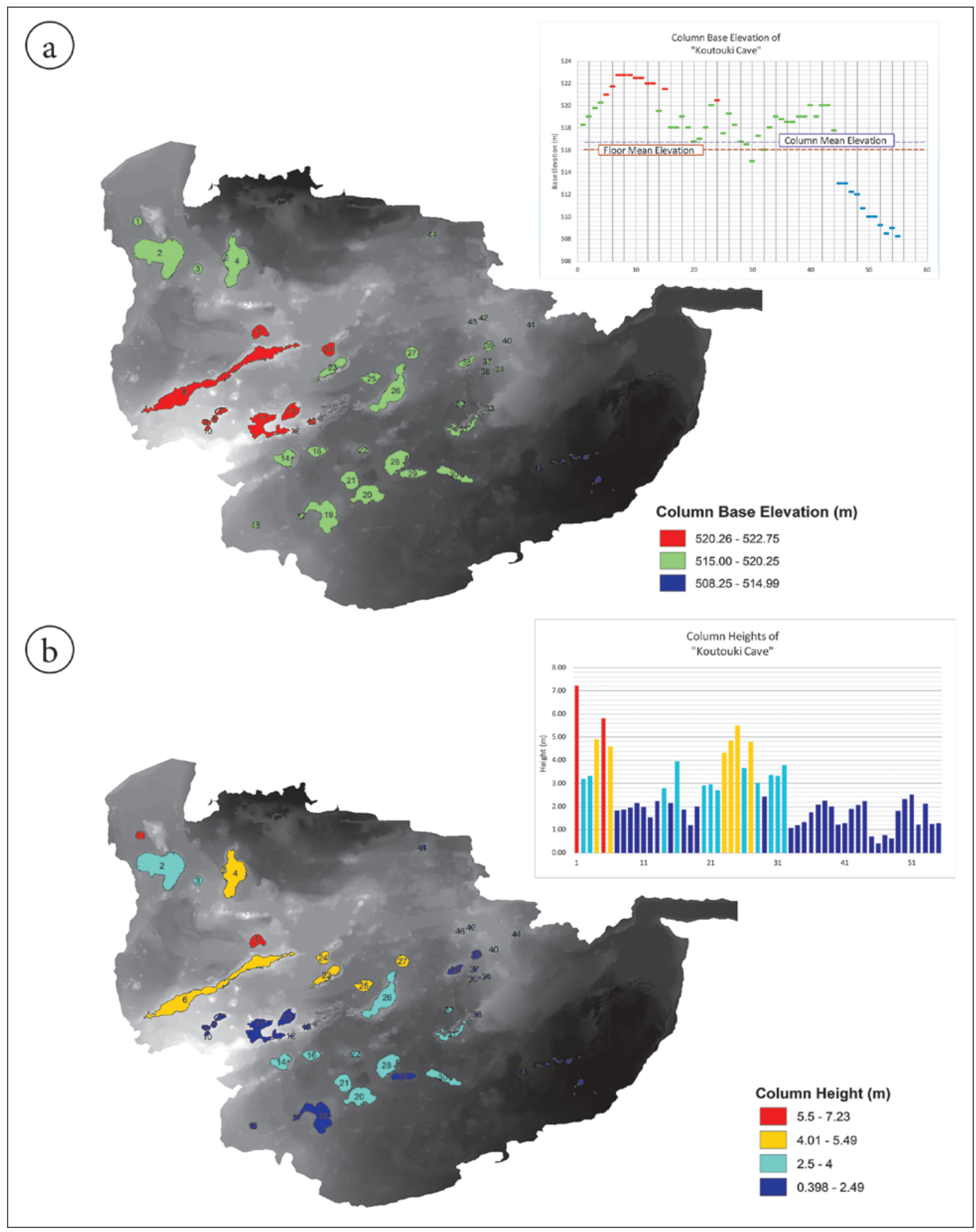

Fig. 9: (a) Column classification according to their base elevation. The highest base elevation altitudes are located at the westernmost and the lowest at the easternmost parts of the cave. The highest percentage of columns was based on the mean elevation of the cave (516.5 $m$ ), (b) Column classification according to the column height. The highest is located also on the west side of the cave at $7.23 \mathrm{~m}$ (column no. 1) and $5.8 \mathrm{~m}$ (columns no. 5) height. 
volume). The DSM subsets are delimited by the column base contour, which was used as a reference plane. The volume was calculated by this algorithm, excluding all the other altitude values.

The volume of the open space of the subsurface cavity was calculated by subtracting the floor DSM pixel values from the roof ones respectively, using a raster calculator and the new resulted raster values range from 0 to $18.1 \mathrm{~m}$, yielding the pixel-based distance between the roof and the floor of the cave. The highest vertical distance difference between the roof and the floor of the cave was found at a location very close to the natural entrance, reaching the maximum calculated value of 18.1 $\mathrm{m}$ (Fig. 8d). The oblique conformation of the natural entrance prevents it from being the area with the highest pixel-based difference, even though the resulted raster values are also included in the class with the highest ones. Taking under consideration the restrictions specifications of the equipment, we accept that there was no laser reflectance at distances greater than $30 \mathrm{~m}$ (or $\sim 28 \mathrm{~m}$ if we take into consideration the human height during the data acquisition), so it was not possible to acquire the entire natural entrance till reaching the open air and therefore, no raster calculations could be carried out at the furthest endings of this natural tunnel.

This new raster layer was titled Digital Volume Model of the cavity space and by doing the math by summarizing the multiplication results of the pixel dimensions $(0.05 \mathrm{~m})$ and the pixel values (corresponding to the roof/floor distance) for all the included pixels, we calculated that its volume is $6,804.11 \mathrm{~m}^{3}$. If we add the volume of the columns, which was calculated previously at 91.27 $\mathrm{m} 3$, we reach the order of the volume of $6,900 \mathrm{~m}^{3}$, which corresponds to the karst cavity volume right before the speleothem deposition.

\section{INTERNAL AND EXTERNAL JOINT MEASUREMENTS}

The tectonic approach of our study, involved measuring the geological structures inside and outside the cave and

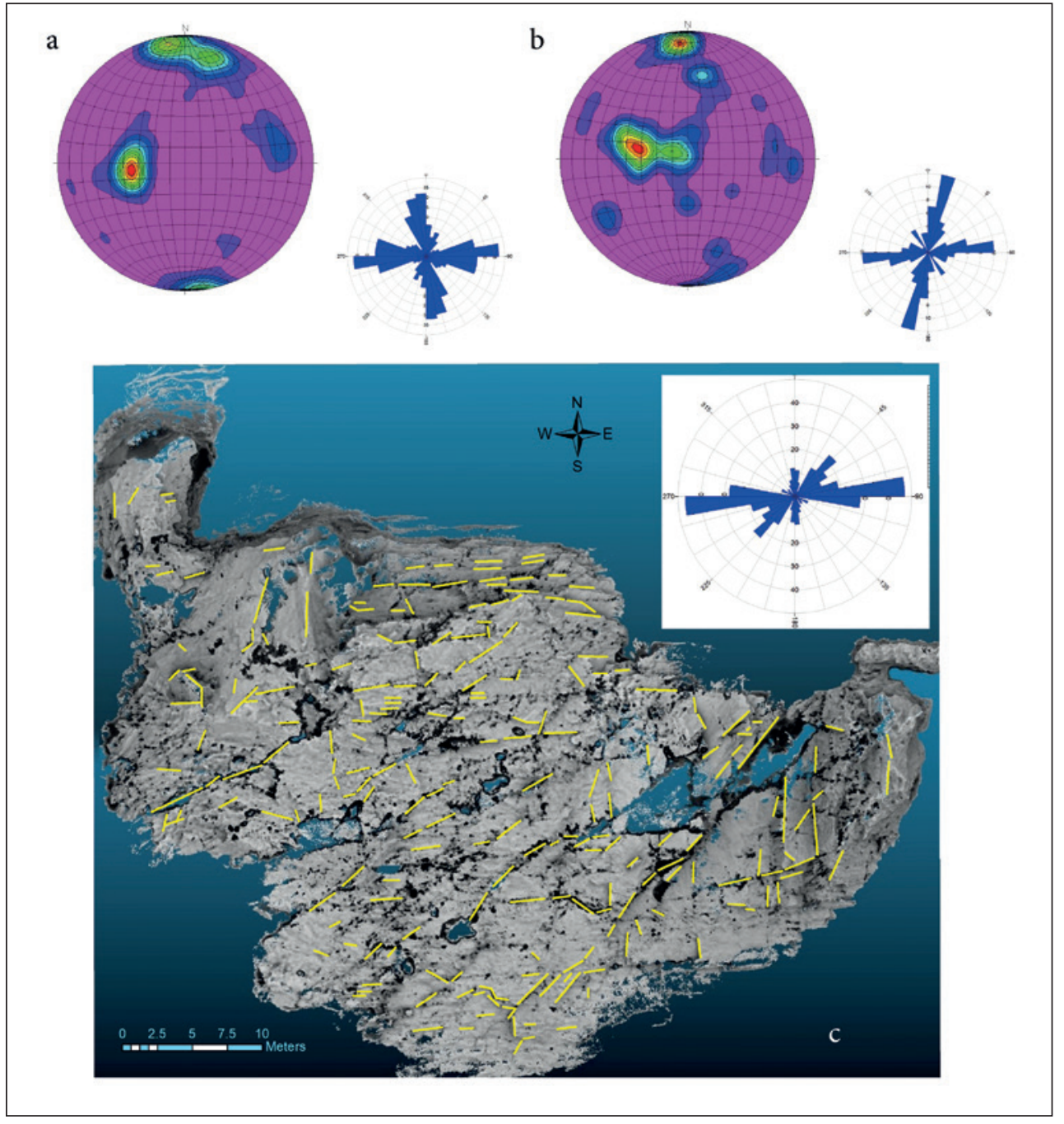

Fig. 10: (a) Statistical analysis of all 447 discontinuities, measured at the marble outcrop outside the Koutouki cave, (b) Statistical analysis of all 130 discontinuities measured inside the Koutouki cave, (c) Filtered Roof Digital Relief and manually digitized discontinuities and their orientation statistical analysis showing that the main joint group is trending $E-W$. 
defining the tectonic kinematics of faulted structures, comparing them with the existing literature (Idrees \& Pradhan 2018).

The entire mountain of Hymettus constitutes an anticline which is part of a series of folds with axis direction NE-SW and Koutouki Cave is situated on the eastern side of this anticline which dips into the Messogia Region and is situated in the Jurassic marbles (Lower Marble unit). According to Dermitzakis and Lekkas (1977), and after collecting and statistically processing a relatively small number of structural discontinuities, they grouped them into 4 significant joint systems in the wider area of Koutouki Cave. The primary joint sets are trending $\mathrm{E}-\mathrm{W}\left(90^{\circ}\right.$ $\left.-270^{\circ}\right)$ and $\mathrm{N}-\mathrm{S}\left(10^{\circ}-190^{\circ}\right)$ while the two secondary joint sets trends are NNE - SSW $\left(25^{\circ}-205^{\circ}\right)$ and NE $\operatorname{SW}\left(50^{\circ}-230^{\circ}\right)$.

The latter was compared to new structural measurements, conducted by our research group. Starting from a wider area - of a diameter of $300 \mathrm{~m}$ outside the cave - we collected more than 150 structural discontinuities by the use of a traditional handheld compass. Simultaneously, we took advantage of the evolution of technology by using an android smartphone which helped us find easier ways for measuring and capturing the orientation of planar and linear features in the field. The smartphones also made data collection more efficient and accurate and they assisted with the ease of taking several readings in a minimum amount of time. We used the mobile application Fieldmove Clino of Midland Valley (Vaughan et al. 2014) for this process. Clino takes advantage of the smartphone internal digital compass - clinometer and uses it for capturing the dip and dip direction of the planar discontinuity surfaces. Therefore, we collected more than 300 discontinuities with affordable location information many times followed by photographs, within a short time (Fig. 10a).

Furthermore, despite the difficult physical conditions, we applied the same method inside the cave by taking 30 measurements using the handheld compass and 100 measurements by the use of Clino (Novakova \& Pavlis 2017; Cawood et al. 2017) (Fig. 10b).

In total, from both outside and inside the cave, we measured more than 570 discontinuities that we classified into four groups. The two main groups are trending $\mathrm{E}-\mathrm{W}$ and N-S. Compared to the existing bibliography, the measurements agreed. There are two secondary groups of discontinuities, one trending NE-SW and one NW-SE.

In addition, we have digitalized all the discontinuities that were evident in the mesh we generated to accomplish more accurate results (Fig. 10c). The orientation of the digitalized discontinuities trending N-S, E-W, and NE-SW is the same as the orientation of the cave's columns.

\section{CONCLUSIONS AND DISCUSSION}

The 3D point data analysis allowed us to create a complete and accurate 3D model of Koutouki Cave. Besides, we produced 3D models in smaller parts of the cavity for better quality results and easier point cloud management. The 3D meshes have been filtered by erasing all the noise that was present in the initial point cloud. The data collection process lasted approximately less than an hour, starting from the artificial entrance of the cave and in a circular way until we met our initial examination point. Comparing the time that the data acquisition took place and the density along with the quality of the data, we come to the conclusion that a second scanning of the cave preferably going the opposite direction could increase the completeness of the point cloud. Concurrently, a very important technical point is that during the scan that not many people should be present during this study, especially when they are not needed. The presence of too many people creates additional noise in the point cloud and makes it difficult for the user to process the data. It would be more accurate for the operator to scan the cave alone to decrease the noise errors caused by unnecessary points, which might exceed $10 \%$ of the dataset. Additionally, according to the previous observations, we concluded that the best process is to manually divide the roof and floor of the cave to exclude all the noise and to clear the point cloud during data processing.

The preprocessed point cloud gives pieces of information about the karst system that are very significant to understand the speleogenetic processes. The column extraction and the calculations were generated by using geoinformation data with high precision grade. After the identification of 55 columns and their spatial distribution throughout the cave floor, it is obvious that the cave development/speleogenesis started from the westernmost part, where the widest and highest columns are located. Nevertheless, this is the exact area where the height difference between the floor and the roof is much larger, not to mention that this is where the natural entrance is found. These observations yield that the westernmost part of the cave widens at a higher rate than the rest of 
the cave, which is developed more to the east, where the artificial entrance has been created.

The results of the statistical analysis of the measured tectonic fractures inside and outside the cave, led to the conclusion that the cave was developed along the south-east dipping, stratigraphic bedding of the bedrock (marble), which is in agreement with previous studies (Dermitzakis \& Lekkas 1977). The short and wide corridors followed by smaller columns in height were formed by the chemical dissolution of the water through the openings at the bedding of the marble. On the contrary, higher and narrow corridors were formed along the joint sets trending. The comparison to the speleothem analysis shows the association between the high corridors and high columns. Also, the speleothem formations show much higher growth to the west and northwest, with significantly larger volumes of calcitic material deposited. At this section of the cave, the vertical distance between the floor and the ceiling is much higher than at the south and east side, where this height difference gradually diminishes. The shape of the columns is relatively smaller, either due to their height or to volume properties.

The generation of the Digital Volume Model of the cavity space of Koutouki Cave is quite enlightening, especially for understanding the formation of the cave. The mathematical simulation of this geomorphological entity in high detail and accuracy led us to a reliable conclusion about the actual speleogenesis sequence, which in turn gave us the basis for the safer and environmentally friendlier exploitation of this very historic monument.

\section{ACKNOWLEDGMENTS}

The authors would like to aknowledge the Ephorate of Palaeoanthropology and Speleology of the Ministry of Culture and especially its Director A. Darlas, for giving the permition to the scientific team for doing fieldwork in the cave. Special thanks to Landmark-Loutridis company for supporting this research effort by letting us use the equipment and providing us the GeoSLAM - REVO point cloud data, as well as to Hellenic Speleological Society for the support by giving us access to the historical archives. The authors would like to express their sincere appreciation to Dr. Nadja Zupan Hajna for improving the initial manuscript.

\section{REFERENCES}

Ballesteros, D., Jiménez-Sánchez, M., García-Sansegundo, J. \& M. Borreguero, 2014: SpeleoDisc: A 3-D quantitative approach to define the structural control of endokarst: An application to deep cave systems from the Picos de Europa, Spain.- Geomorphology, 216, 141-156. https://doi.org/10.1016/j. geomorph.2014.03.039

Buchroithner, M., 2015: Mountain cartography 'down under' - Speleological 3D Mapping.- Wiener Schriften zur Geographie und Kartographie, 21, 93-204.

Buchroithner, M.F. \& T. Gaisecker, 2009: Terrestrial Laser Scanning for the Visualization of a Complex Dome in an Extreme Alpine Cave System.- Photogrammetrie - Fernerkundung - Geoinformation, 4, 329339. https://doi.org/10.1127/1432-8364/2009/0025

Canevese, E., Forti, P. \& R. Tedeschi, 2013: New Acquisition, 3D Modelling, and Data Use Methods: The Laser Scanning Survey of Re Tiberio Cave.- In: Fillipi, M. \& P. Bosak (eds.) Proceedings of the $16 t^{\text {h }}$ Inter- national Congress of Speleology, 21 $1^{\text {st }}$-28 ${ }^{\text {th }}$ July 2013, Brno. Czech Speleological Society, 340-345, Brno.

Cawood, A.J., Bond, C.E., Howell, J.A., Butler, R.W.H. \& Y. Totake, 2017: LiDAR, UAV or compass-clinometer? Accuracy, coverage and the effects on structural models.- Journal of Structural Geology, 98, 67-82. https://doi.org/10.1016/j.jsg.2017.04.004

Dermitzakis, M. \& S. Lekkas, 1977: Structural conditions and speleogenesis of the cave "Koutouki" in Peania Attica.- Bulletin of Hellenic Speleological Society, $14,1,42-63$.

Duguet, F. \& D. Girardeau-Montaut, 2004: Rendu en Portion de Ciel Visible de Gros Nuages de Points 3D.- Actes des journees de l'AFIG, 11.

Durrant-Whyte, H. \& T. Bailey, 2006: Simultaneous localization and mapping: part I.- IEEE Robotics \& Automation Magazine, 13, 2, 99-110. https://doi. org/10.1109/MRA.2006.1638022

ESRI, 2011: ArcGIS Desktop, Release 10.- Redlands, California. 
Gallay, M., Kaňuk, J., Hochmuth, Z., Meneely, J.D., Hofierka, J. \& V. Sedlák, 2015: Large-scale and high-resolution 3-D cave mapping by terrestrial laser scanning: a case study of the Domica Cave, Slovakia.International Journal of Speleology, 44, 3, 277-291. http://dx.doi.org/10.5038/1827-806X.44.3.6

Gallay, M., Hochmuth, Z., Kaňuk, J. \& J. Hofierka, 2016: Geomorphometric analysis of cave ceiling channels mapped with 3-D terrestrial laser scanning.- Hydrology and Earth System Science, 20, 5, 1827-1849. http://dx.doi.org/10.5194/hess-20-1827-2016

Girardeau-Montaut, D., 2011: Cloud Compare v.2.10.2, OpenSource Project.- Grenoble, France.

Holenstein, C., Zlot, R. \& M. Bosse, 2011: Watertight surface reconstruction of caves from 3D laser data.- In: Proceedings IEEE/RSJ International Conference on Intelligent Robots and Systems, 25 $5^{\text {th }}-30^{\text {th }}$ September 2011, San Francisco. IEEE, 3830-3837, San Francisco. http://dx.doi.org/10.1109/IROS.2011.6095145

Idrees, M.O. \& B. Pradhan, 2018: Geostructural stability assessment of cave using rock surface discontinuity extracted from terrestrial laser scanning point cloud.- Journal of Rock Mechanics and Geotechnical Engineering, 10, 3, 534-544. https://doi. org/10.1016/j.jrmge.2017.11.011

Kazhdan, M., Bolitho, M. \& H. Hoppe, 2006: Poisson surface reconstruction.- In: Polthier, K. \& A. Sheffer (eds.) Proceedings $4^{\text {th }}$ Eurographics symposium on Geometry processing, 26 ${ }^{\text {th }}-28^{\text {th }}$ June 2006, Cagliari. The Eurographics Association, 61-70, Goslar.

Kazhdan, M. \& H. Hoppe, 2013: Screened poisson surface reconstruction.- Association for Computing Machinery Transactions on Graphics, 32, 3, 1-13. https://doi.org/10.1145/2487228.2487237

Kershaw, B., 2012: Managing the survey information of the caves of Judbarra/Gregory National Park, Northern Territory.- Helictite, 41, 87-94.

Lekkas, S. \& S. Lozios, 2000: Tectonic structure of Mt. Hymittos.- Annales Géologiques des Pays Helleniques, 38, 47-62.

Lindgren, S. \& F. Galeazzi, 2013: 3D laser scanning in cave environment: The case of las cuevas, Belize acquisition of the cave system and excavation area.In: Proceedings Digital Heritage International Congress, $28^{\text {th }}$ October $-1^{\text {st }}$ November 2013, Marseille, 219-222. Institute of Electrical and Electronics Engineers, Marseille. https://doi.org/10.1109/DigitalHeritage.2013.6743737
Mariolakos, I. \& S. Lekkas, 1974: Hydrological Conditions of Koropi Basin, Attica.- Annales Géologiques des Pays Helleniques, 24, 186-250.

Mugnier, C., 2002: Grids and Datums: The Hellenic Republic.- Photogrammetric Engineering and Remote Sensing, 68, 12, 1237-1238.

Novakova, L. \& T.L. Pavlis, 2017: Assessment of the precision of smart phones and tablets for measurement of planar orientations: A case study.- Journal of Structural Geology, 97, 93-103. https://doi.org/10.1016/j. jsg.2017.02.015

Papavlasopoulou N., 2009: Caves as monuments of nature and civilization; Case studies Koutouki Peanias, Attica and Limnon Kastrion, Kalavriton.- M.Sc. thesis. National and Kapodistrian University of Athens, pp. 166.

Pfister, H., Zwicker, M., Baar, J.V. \& M. Gross, 2000: Surfels: surface elements as rendering primitives.- In: Proceedings $27^{\text {th }}$ annual conference on Computer graphics and interactive techniques, July 2000, New Orleans. ACM Press/Addison-Wesley Publishing Co., 335-342 New York. https://doi. org/10.1145/344779.344936

Rigol-Sanchez, J.P., Stuart, N. \& A. Pulido-Bosch, 2015: ArcGeomorphometry: A toolbox for geomorphometric characterisation of DEMs in the ArcGIS environment.- Computers and Geosciences, 85, part A, 155-163. https://doi.org/10.1016/j.cageo.2015.09.020

Silvestre, I., Rodrigues, J.I., Figueiredo, M. \& C. VeigaPires, 2015: High-resolution digital 3D models of Algar do Penico Chamber: limitations, challenges, and potential.- International Journal of Speleology, 44, 1, 25-35. http://dx.doi.org/10.5038/1827806X.44.1.3

Vaughan, A., Collins, N., Krus, M. \& P. Rourke, 2014: Recent development of an earth science app-FieldMove Clino.- In: Proceedings EGU general assembly conference, $2^{\text {th }}$ April - $2^{\text {nd }}$ May 2014, Vienna, 14751.

Warild, A., 2007: Vertical - A technical manual for cavers.- Speleological Research Council Ltd, pp. 206, Broadway, Sydney, NSW.

Zlot, R. \& M. Bosse, 2014 Three-Dimensional Mobile Mapping of Caves.- Journal of Cave and Karst Studies, 76, 3, 191-206. https://doi.org/ $10.4311 / 2012 \mathrm{EX} 0287$ 